\title{
Tickborne Arbovirus Surveillance in Market Livestock, Nairobi, Kenya
}

\author{
Rosemary Sang, ${ }^{*}$ Clayton Onyango, ${ }^{*}$ John Gachoya, ${ }^{*}$ Ernest Mabinda, ${ }^{*}$ Samson Konongoi, ${ }^{*}$ \\ Victor Ofula, ${ }^{*}$ Lee Dunster, ${ }^{*}$ Fred Okoth, ${ }^{*}$ Rodney Coldren, $\dagger$ Robert Tesh, $\ddagger$ \\ Amelia Travassos da Rosa, $\ddagger$ Stacy Finkbeiner,§ David Wang,§ Mary Crabtree,, and Barry Miller
}

To identify tickborne viruses circulating in Kenya and the surrounding region, we conducted surveillance at abattoirs in Nairobi, Kenya. Species of ticks collected included Rhipicephalus pulchellus (56\%), Amblyomma gemma (14\%), R. appendiculatus (8\%), A. variegatum (6\%), and others. A total of 56 virus isolates were obtained, 26 from $A$. gemma, 17 from $R$. pulchellus, 6 from $A$. variegatum, and 7 from other species. Virus isolates included Dugbe virus (DUGV), an unknown virus related to DUGV, Thogoto, Bhanja, Kadam, Dhori, Barur, and foot-and-mouth disease (FMDV) viruses. This is the first report of Dhori virus isolation in East Africa and the first known isolation of FMDV associated with tick collection. Our results demonstrate the potential for tickborne dissemination of endemic and emergent viruses and the relevance of $A$. gemma in the maintenance of tickborne viruses in this region.

$\mathrm{V}$ iruses transmitted by blood-feeding arthropods (arboviruses) are responsible for some of the most serious emerging infectious disease problems facing the world today. Arthropodborne viruses constitute the largest biologic group of vertebrate viruses. Their considerable number and diversity suggest that arthropod vector transmission offers distinct survival benefits for the virus. Approximately 50\% of arbovirus isolations from field-collected arthropods are from mosquitoes, and $25 \%$ are from ticks; however, this difference may represent a sampling bias, since many more mosquitoes are collected and tested for virus than ticks. To investigate the abundance of tickborne arboviruses in Kenya and the surrounding region,

*Kenya Medical Research Institute, Nairobi, Kenya; †United States Army Medical Research Unit, Nairobi, Kenya; łUniversity of Texas Medical Branch, Galveston, Texas, USA; §Washington University School of Medicine, Saint Louis, Missouri, USA; and ๆCenters for Disease Control and Prevention, Fort Collins, Colorado, USA we collected and tested ticks infesting livestock driven to market at 2 major abattoirs in Nairobi, Kenya. These abattoirs receive the bulk of animals slaughtered for Nairobi and its environs, which is the largest livestock market in the country. Approximately $30 \%$ of animals slaughtered in these abattoirs come from within Kenya; the rest are from neighboring countries, including Ethiopia, Sudan, Somalia, and Tanzania.

Among pastoral communities in this region, livestock are frequently maintained in enclosures close to human habitation, and small ruminants sometimes sleep inside houses overnight for security reasons. Such practices increase the potential for zoonotic virus transmission between animals and humans. Poor husbandry and grazing practices put great pressure on land resources, which results in the need to continuously move large numbers of animals, especially cattle, in search of pasture. In some parts of East Africa, these pastoral communities exist near wildlife parks, and wildlife and livestock sometimes mix, which allows transfer of ticks and possibly viruses between these animal groups. Additionally, livestock marketing practices allow movement of animals across borders in the region, which allows ticks and tickborne viruses to move between countries.

Previous surveillance reports based on virus isolations or serologic studies in cattle from Kenya, the Central African Republic, and South Africa have identified tickborne arboviruses from the Bunyaviridae, Flaviviridae, Rhabdoviridae, Reoviridae, and Orthomyxoviridae (1-4). The genus Nairovirus, family Bunyaviridae, includes 37 named viruses that are principally tickborne (5-7). The most serious human pathogen among the tickborne viruses in the African region is Crimean-Congo hemorrhagic fever virus (CCHFV), a member of the Nairovirus genus that can cause fatal hemorrhagic disease $(8,9)$. Outbreaks of 
Crimean-Congo hemorrhagic fever have occurred in People's Republic of China, South Africa, Pakistan, and Russia (10-12). The first reported human case of this disease in Kenya occurred recently at a farm that was heavily infested by ticks (13). Nairobi sheep disease virus (NSDV), also in the genus Nairovirus, causes fever, hemorrhagic gastroenteritis, and abortion in sheep and goats in East Africa (14). Epizootics of NSDV have been reported in parts of Africa where susceptible herds of sheep have been moved to NSDV-endemic areas, resulting in decimation of whole herds (14). Dugbe virus (DUGV), another member of the Nairovirus genus, has been repeatedly confirmed in tickborne virus surveys in Africa and causes febrile illness and thrombocytopenia in humans (2). Bhanja virus (BHAV), an unassigned member of the Bunyaviridae family, has also been isolated in this region $(1,2)$. Other tickborne viruses present in Africa include Thogoto virus (THOV) (genus Thogotovirus, family Orthomyxoviridae), isolated in Kenya; Barur virus (family Rhabdoviridae), isolated in Somalia; and Kadam virus (KADV) (genus Flavivirus, family Flaviviridae) and Chenuda virus (genus Orbivirus, family Reoviridae), confirmed serologically in cattle in South Africa $(1,2,4)$.

Our study isolated and identified 6 previously known tickborne arboviruses, including DUGV, BHAV, THOV, Dhori virus (DHOV), KADV, and Barur virus. In addition, 2 viruses related to DUGV were isolated. An unexpected result of this study was the isolation of foot-and-mouth disease virus (FMDV) from tick pools.

\section{Materials and Methods}

\section{Tick Collection and Processing}

Ticks were collected from the hides of flayed animals between September and November 1999 at the Njiru and Dagoretti abattoirs, on the outskirts of Nairobi, Kenya. Attached ticks were pulled off manually and placed in sterile plastic vials, which were loosely capped and transported to the laboratory. The origin of individual sampled animals could not be determined. All animals to be slaughtered for the day were put in 1 enclosure, irrespective of origin.

In the laboratory, ticks were washed twice with sterile water to remove excess particulate contamination from animal hides, rinsed once with $70 \%$ ethanol, and then rinsed twice with minimum essential medium (MEM), with antimicrobial agents $(100 \mathrm{U} / \mathrm{mL}$ penicillin, 100 $\mu \mathrm{g} / \mathrm{mL}$ streptomycin, and $1 \mu \mathrm{L} / \mathrm{mL}$ amphotericin B). Ticks were identified by sex and species by using appropriate identification keys $(15,16)$, transferred to sterile vials, and stored at $-80^{\circ} \mathrm{C}$ until homogenized for virus isolation. Voucher specimens were prepared in ethanol, and identifications were reviewed at the International Centre of Insect
Physiology and Ecology, Nairobi. Ticks were later thawed at room temperature, identifications were confirmed, and ticks were pooled into groups of 2 to 50 , depending on the size of the ticks and according to species, collection dates, and sites. Each pool was homogenized by using 90-mesh alundum in a prechilled, sterile mortar and pestle with 1.6-2 mL ice-cold bovine albumin (BA)-1 medium (1× medium 199 with Earle's salts, 1\% BA, $100 \mathrm{U} / \mathrm{mL}$ penicillin, $100 \mu \mathrm{g} / \mathrm{mL}$ streptomycin, and $1 \mu \mathrm{L} / \mathrm{mL}$ amphotericin B). The homogenates were clarified by low-speed centrifugation at $1,500 \mathrm{rpm}$ for 15 minutes at $4^{\circ} \mathrm{C}$, and supernatants were aliquoted and stored at $-80^{\circ} \mathrm{C}$. In the case of Hyalomma species, the primary vectors of CCHFV, each pool was screened by reverse transcription-polymerase chain reaction (RT-PCR) for CCHFV before tissue culture injection was conducted (Table 1).

\section{Virus Isolation}

For virus isolation in cell culture, Vero cells were grown in $25-\mathrm{cm}^{2}$ cell culture flasks to $80 \%$ confluency in MEM with $10 \%$ fetal bovine serum (FBS), $2 \%$ glutamine, $100 \mathrm{U} / \mathrm{mL}$ penicillin, $100 \mu \mathrm{g} / \mathrm{mL}$ streptomycin, and 1 $\mu \mathrm{L} / \mathrm{mL}$ amphotericin B. Cells were rinsed with sterile saline, and $0.2 \mathrm{~mL}$ clarified tick homogenate was added followed by injection at $37^{\circ} \mathrm{C}$ for 45 minutes to allow virus adsorption. After incubation, cells were rinsed with saline and maintenance medium (MEM with Earle's salts, with $5 \%$ FBS, $2 \%$ glutamine, $100 \mathrm{U} / \mathrm{mL}$ penicillin, $100 \mu \mathrm{g} / \mathrm{mL}$ streptomycin, and $1 \mu \mathrm{L} / \mathrm{mL}$ amphotericin B) was added. Cells were incubated at $37^{\circ} \mathrm{C}$ and observed daily for signs of cytopathic effects (CPE). The pooled infection rate program (PooledInfRat, Centers for Disease Control and Prevention, Fort Collins, CO, USA; http://wwwcdcgov/ ncidod/dvbid/westnile/softwarehtm) was used to compare virus infection rates in the tick species collected and processed in this study.

\section{Virus Identification}

Agents causing CPE in tissue culture were initially identified to virus group by using the indirect fluorescent antibody assay (IFA) on spot slides of infected Vero cells with polyvalent mouse hyperimmune ascitic fluids obtained from the National Institutes of Health Reference Reagents Program. Fluorescein isothiocyanate-conjugated goat anti-mouse immunoglobulin $\mathrm{G}$ was the secondary antibody.

RT-PCR was also used to identify most of the virus isolates obtained from tissue culture. RNA was extracted from cell culture supernatants with the QIAamp Viral RNA kit (Qiagen, Valencia, CA, USA) according to the manufacturer's recommended protocol. RT-PCR was performed with the Titan One Tube RT-PCR kit (Roche, Indianapolis, IN, USA) with primers mainly targeting the 
RESEARCH

Table 1. Reverse transcription-polymerase chain reaction primers used for arbovirus isolation, Nairobi, Kenya

\begin{tabular}{|c|c|c|c|}
\hline Virus target & $\begin{array}{l}\text { Target } \\
\text { gene }\end{array}$ & $\begin{array}{c}\text { Primer } \\
\text { designation }\end{array}$ & Primer sequences ${ }^{*}$ \\
\hline \multirow{2}{*}{$\begin{array}{l}\text { Crimean-Congo } \\
\text { hemorrhagic fever }\end{array}$} & $\mathrm{N}$ & CCHF F2 & TGGACACCTTCACAAACTC \\
\hline & & $\mathrm{CCHF} \mathrm{R3}$ & GACAAATTCCCTGCACCA \\
\hline \multirow[t]{2}{*}{ Dugbe } & $\mathrm{N}$ & DG S1 & TCTCAAAGACAAACGTGCCGCAG \\
\hline & & DG S5 & TGCAACAACTGGATGTGTGA \\
\hline \multirow{2}{*}{$\begin{array}{l}\text { Nairobi sheep } \\
\text { disease }\end{array}$} & $\mathrm{N}$ & NSD $12 f$ & GAATGGTCGAACGTGGAC \\
\hline & & NSD $16 r$ & TGCTGTCAGGACACCAGG \\
\hline \multirow[t]{2}{*}{ Thogoto } & $\mathrm{N}$ & THO NF & CCTGCAGGGGCGGAAGTTATG \\
\hline & & THO NR & AAAATCCTCGCAGTTGGCTATCA \\
\hline \multirow[t]{2}{*}{ Flaviviruses } & NS5 & FLAVI fu2 & GCTGATGACACCGCCGGCTGGGACAC \\
\hline & & FLAVI cfd3 & AGCATGTCTTCCGTGGTCATCCA \\
\hline \multirow{2}{*}{$\begin{array}{l}\text { Bunyamwera and } \\
\text { California serogroups }\end{array}$} & $\mathrm{N}$ & $\mathrm{BCS} 82 \mathrm{C}$ & ATGACTGAGTTGGAGTTTCATGATGTCGC \\
\hline & & BCS332V & TGTTCCTGTTGCCAGGAAAAT \\
\hline \multirow[t]{2}{*}{ Rift Valley fever } & G2 & RVF-M-727f & GGAACCCCTGCATGAAAGAGA \\
\hline & & RVF-M-1565r & CGATCCTGTGACGCAAACTC \\
\hline \multirow[t]{2}{*}{ Dhori } & $N$ & DHO NF2 & TGGTACCCTTTTCTTGCTTCACTCC \\
\hline & & DHO NR2 & TGCTCTTCCTCGGCTCAAACACCA \\
\hline \multirow[t]{2}{*}{ Babanki } & $\mathrm{C} / \mathrm{E} 3$ & BAB $1007 f$ & TGGCCATGGAAGGTAAGGTAAT \\
\hline & & BAB 1569r & TATGGCGTTGAGCAGGGTATC \\
\hline \multirow[t]{2}{*}{ Hazara } & $\mathrm{N}$ & HAZ $803 f$ & CTGGTTGAGCTAGAGGGGAAAGACG \\
\hline & & HAZ 1304r & GGGCGGCATCATCGGGACTG \\
\hline \multirow[t]{2}{*}{ Coxsackie B4 } & Pol & $\operatorname{cox} 6749 f$ & ACTTTGTGAGAGGGGGTATGC \\
\hline & & $\operatorname{cox} 7151 \mathrm{r}$ & ACGTGGTATTGGGTGTTTTT \\
\hline \multirow[t]{2}{*}{ Koutango } & NS5 & KOU $176 f$ & TCAGGGAGGTGGGAGGTAAAC \\
\hline & & KOU $734 r$ & TCATGCCATCCAACAGAAGGT \\
\hline \multirow[t]{2}{*}{ Saboya } & NS5 & SAB $226 f$ & GCAGGCTGGGACACAAAGAT \\
\hline & & SAB $815 r$ & CTACAAGGGGCAATGATGGTTC \\
\hline \multirow[t]{2}{*}{ Ndelle } & $\lambda 3$ & NDE $655 f$ & GGGGTTTTCTGGCTAATGTCAC \\
\hline & & NDE $1238 \mathrm{r}$ & GGGCCTGTCCAGTCTTTTTG \\
\hline \multirow[t]{2}{*}{ Middleburg } & E2 & MID $1939 f$ & TACATGCCCCGAAGGTGACT \\
\hline & & MID 2458r & CGGGATGGTGTTCGGTAAAG \\
\hline
\end{tabular}

known African tickborne viruses (Table 1). References are available from the authors for previously published primers. All other primers were designed for this study to amplify a specific fragment from the virus listed and have not been tested for cross-reactivity with other related or unrelated viruses. RT-PCR was also performed on RNA extracted from uninfected Vero cells as a negative control. Amplified DNA fragments were visualized by electrophoresis on $0.8 \%-1.0 \%$ agarose gels. DNA fragments were extracted from gels with the QIAquick Gel Extraction Kit (Qiagen), and DNA was eluted in $20 \mu \mathrm{L} 10$ $\mathrm{mmol} / \mathrm{L}$ Tris- $\mathrm{HCl}, \mathrm{pH} 8.5$, and stored at $-20^{\circ} \mathrm{C}$. RT-PCR fragments were sequenced with the CEQ DCTS Quick Start kit (Beckman Coulter, Inc., Fullerton, CA, USA) with listed primers and analyzed with a CEQ 8000 automated sequencer (Beckman Coulter, Inc.). Both strands of DNA were sequenced. Nucleic acid sequences were compared with the GenBank database by using the BLAST program (http:www.ncbi.nlm.nih.gov/BLAST).

Additional methods used to identify selected isolates included complement fixation (CF) and hemagglutinationinhibition tests (17) and panviral microarray-based geno- typing (18). Alignment of nucleic acid and deduced protein sequences was conducted by using the MegAlign program (Lasergene 6.1, DNASTAR, Inc., Madison, WI, USA); phylogenetic and molecular evolutionary analyses were conducted with MEGA version 3.0 (http://www.megasoftware.net).

\section{Results}

\section{Tick Collection}

A total of 15,851 ticks were collected and processed in 1,071 pools for virus isolation. Species of ticks collected and their proportions in the collection are shown in Table 2. The predominant species collected was Rhipicephalus pulchellus (56\%), followed by Amblyomma gemma, $R$. appendiculatus, and A. variegatum. Other species were sampled in smaller numbers. However, the calculated virus pooled infection rate was higher for $A$. gemma than for $R$. pulchellus (Table 2). The number of Hyalomma specimens collected was comparatively small (3\%). These species are the primary vectors of CCHFV; this agent was not among the viruses isolated. 
Table 2. Tick species collected and their virus yield, Kenya

\begin{tabular}{lccc}
\hline Species & $\begin{array}{c}\text { No. } \\
\text { collected }\end{array}$ & $\begin{array}{c}\text { No. } \\
\text { virus } \\
\text { isolates }\end{array}$ & $\begin{array}{c}\text { Pooled } \\
\text { infection } \\
\text { rate }\end{array}$ \\
\hline $\begin{array}{l}\text { Amblyomma } \\
\text { variegatum }\end{array}$ & 994 & 6 & 6.16 \\
$\begin{array}{l}\text { A. gemma } \\
\text { A. lepidum }\end{array}$ & 2,160 & 26 & 11.05 \\
A. coharens & 963 & 4 & 4.24 \\
$\begin{array}{l}\text { Boophilus } \\
\text { decoloratus }\end{array}$ & 4 & 0 & 0 \\
Hyalomma & 985 & 1 & 1.01 \\
truncatum & 270 & 0 & 0 \\
H. albiparmatum & 112 & 0 & 0 \\
H. rufipes & 96 & 0 & 0 \\
H. dromedarii & 1 & 0 & 0 \\
Rhipicephalus & 1,228 & 2 & 1.63 \\
appendiculatus & 146 & 0 & 0 \\
R. evertsi & 8,892 & 17 & 2.48 \\
R. pulchellus & 15,851 & 56 & \\
Total & & & \\
\hline
\end{tabular}

\section{Virus Isolation and Identification}

A total of 56 virus isolates were obtained from 51 tick pools; 52 of the 56 viruses were identified (Table 3). Five pools contained 2 different viruses. All of the isolated viruses caused CPE in Vero cells. The observed onset of CPE was 4-10 days postinfection. In the initial identification by IFA, 6 isolates reacted positively with the Thogoto group-specific antiserum (polyvalent 4), 33 isolates reacted with the Congo group-specific antiserum, 1 isolate reacted with the flavivirus group-specific antiserum (group B), and 1 isolate reacted with antiserum that included specificity to DHOV (polyvalent 10).

Forty-five virus isolates were identified by using RTPCR and nucleic acid sequencing with primers specific to known tickborne viruses or by CF assay or microarray- based genotyping. The identified isolates included 26 DUGV, 6 THOV, 6 Barur virus, 3 FMDV, 2 BHAV, 1 DHOV, and $1 \mathrm{KADV}$. DUGV was isolated most frequently (46\%). Most DUGV isolates were recovered from $A$. gemma (62\%), whereas the most commonly sampled tick, $R$. pulchellus, yielded only 2 DUGV isolates (8\%) (Table 3).

Two of the virus isolates that were IFA-positive with Congo group antiserum were RT-PCR negative when primers specific for DUGV, CCHFV, Hazara virus, or BHAV, all of which were represented in the antiserum, were used. However, RT-PCR using NSDV nucleocapsid-specific primers and RNA extracted from these isolates produced 3 major bands, including one $\approx 880 \mathrm{bp}$ in size; the expected band size for the NSDV-specific fragment was $887 \mathrm{bp}$. The 880-bp fragment was sequenced, and an alignment of $513 \mathrm{nt}$ (nt) of this sequence with nucleocapsid sequences from DUGV, CCHFV, and NSDV showed $71 \%$, 58\%, and $60 \%$ homology, respectively, which suggests that these isolates were most closely related to DUGV. Alignment of sequences from the 2 isolates showed them to be $95 \%$ homologous. Specific primers were designed for this DUGV-like virus from sequence of the fragment described above. RT-PCR conducted with these primers produced bands of correct size and sequence with RNA from the DUGV-like virus isolates, while RTPCR results using these primers with RNA from DUGV and BHAV were negative. RT-PCR and sequencing of all of the virus isolates using the primers designed from the DUGV-like virus sequence showed 4 additional isolates of this DUGV-like virus; 2 were from pools that also contained DUGV. Sequence homology between all 6 DUGVlike isolates was $95 \%-100 \%$, based on a 508-nt alignment of the S segment of the virus RNA. Of the 6 isolates of this

Table 3. Virus isolates obtained from ticks collected in Nairobi, Kenya

\begin{tabular}{|c|c|c|c|c|c|c|c|c|c|c|}
\hline Species & DUGV & DUGV-like & $\mathrm{BHAV}$ & THOV & $\mathrm{DHOV}$ & KADV & BARV-like & FMDV & Unknown & Total \\
\hline $\begin{array}{l}\text { Amblyomma } \\
\text { variegatum }\end{array}$ & 6 & 0 & 0 & 0 & 0 & 0 & 0 & 0 & 0 & 6 \\
\hline A. gemma & 16 & 5 & 0 & 4 & 0 & 0 & 0 & 0 & 1 & 26 \\
\hline A. lepidum & 2 & 1 & 0 & 1 & 0 & 0 & 0 & 0 & 0 & 4 \\
\hline A. coharens & 0 & 0 & 0 & 0 & 0 & 0 & 0 & 0 & 0 & 0 \\
\hline $\begin{array}{l}\text { Boophilus } \\
\text { decoloratus }\end{array}$ & 0 & 0 & 1 & 0 & 0 & 0 & 0 & 0 & 0 & 1 \\
\hline $\begin{array}{l}\text { Hyalomma } \\
\text { truncatum }\end{array}$ & 0 & 0 & 0 & 0 & 0 & 0 & 0 & 0 & 0 & 0 \\
\hline H. albiparmatum & 0 & 0 & 0 & 0 & 0 & 0 & 0 & 0 & 0 & 0 \\
\hline H. rufipes & 0 & 0 & 0 & 0 & 0 & 0 & 0 & 0 & 0 & 0 \\
\hline H. dromedarii & 0 & 0 & 0 & 0 & 0 & 0 & 0 & 0 & 0 & 0 \\
\hline $\begin{array}{l}\text { Rhipicephalus } \\
\text { appendiculatus }\end{array}$ & 0 & 0 & 1 & 0 & 0 & 1 & 0 & 0 & 0 & 2 \\
\hline$R$. evertsi & 0 & 0 & 0 & 0 & 0 & 0 & 0 & 0 & 0 & 0 \\
\hline R. pulchellus & 2 & 1 & 0 & 1 & 1 & 0 & 6 & 3 & 3 & 17 \\
\hline Total & 26 & 7 & 2 & 6 & 1 & 1 & 6 & 3 & 4 & 56 \\
\hline
\end{tabular}

*DUGV, Dugbe virus; BHAV, Bhanja virus: THOV, Thogoto virus; DHOV, Dhori virus; KADV, Kadam virus; BARV, Barur virus; FMDV, foot-and-mouth disease virus 
virus, 5 (83\%) were from A. gemma pools, and 1 (17\%) was from a pool of $R$. pulchellus. One additional isolate, obtained from a pool of $A$. lepidum, was identified as being DUGV-like by CF test. RT-PCR conducted on RNA extracted from this isolate with the primers designed for the DUGV-like virus described above produced a weak band. Sequence of this product was $\approx 80 \%$ homologous to the other isolates of DUGV-like virus and 70\%, 63\%, 57\%, and 55\% homologous to DUGV, NSDV, CCHFV, and Hazara virus, respectively, which suggests that it may be a different DUGV-like isolate.

Six isolates of THOV were obtained: 4 from pools of $A$. gemma, 1 from A. lepidum, and 1 from $R$. pulchellus. Since the THOV genome is segmented, a portion of each of the 6 genome segments from each isolate was sequenced and compared with available sequence from other THOV isolates to determine if reassortment of virus genome segments had occurred. No evidence was found for reassortment of virus segments. Phylogenetic analysis showed that the THOV isolates were most closely related to other African isolates from Uganda (1996), Kenya (1960), and Nigeria (1969) (data not shown).

The single isolate of DHOV, another member of the tickborne orthomyxovirus group, was obtained from a pool of $R$. pulchellus. A single isolate of KADV, the only African member of the tickborne flavivirus group, was recovered from a pool of $R$. appendiculatus. Six isolates were found by CF test to be indistinguishable from Barur virus, a rhabdovirus. Further characterization of these isolates was not conducted.

Three isolates of FMDV were identified by using panviral microarray-based technology. RNA isolated from viral culture of 1 isolate was reverse transcribed, randomly amplified, and hybridized to panviral DNA microarrays as described (19). Analysis of the hybridization patterns showed extensive hybridization to oligonucleotides derived from FMDV. Based on this result, PCR primers were designed from conserved regions of FMDV to confirm the identity of the virus. A PCR product of $\approx 600 \mathrm{bp}$ was generated; it possessed $97 \%$ nucleotide identity to FMDV serotype SAT3. Two other isolates were identical by CF test.

Four isolates remained unidentified. Three of these were recovered from $R$. pulchellus and 1 from A. gemma. All of these isolates failed to react with the hyperimmune ascites grouping fluids used for the IFA identification procedure and produced negative results in RT-PCR tests when primers specific to known African tickborne viruses were used.

\section{Discussion}

In this study, A. gemma ticks were incriminated for the first time as key vectors or reservoirs of tickborne viruses in the East African region; $46 \%$ of our virus isolates were obtained from this species. Distribution limits of ticks are variable and are influenced by several factors, including climate, vegetation, host density, host susceptibility, and host grazing habits. During previous studies conducted at the Lake Victoria basin in Kenya (1), A. gemma was not collected, most likely because this species is limited to more arid zones. A. gemma is found only in the dry zones of bushwillows (Combretum) and shrub steppe and is much more restricted than A. lepidum to very dry areas. DUGV and DUGV-like viruses were the most frequently isolated viruses in this study (33/56, 59\%), and $64 \%$ of these isolates were from pools of A. gemma. Four of the 6 THOV isolates were obtained from pools of this species as well. Our results suggest that viruses are being actively transmitted in the drier parts of East Africa where $A$. gemma is more common. The pastoral regions, which supply many of the animals slaughtered at abattoirs in Nairobi, are predominantly dry and therefore likely to harbor this tick species in abundance.

The proportion of $R$. appendiculatus collected in this study was small when one considers the distribution of this tick in Kenya and its importance as a pest, a finding that suggests that most sampled cattle came from climatic zones where this species is not abundant. In Tanzania and Kenya, $R$. appendiculatus is most abundant in areas receiving $>1,000 \mathrm{~mm}$ mean annual rainfall. It is absent from xerophytic and dry thicket zones with overgrazed pastures and little grass cover (15). NSDV is mainly transmitted by $R$. appendiculatus, and the virus is found only in areas where this species is abundant (14); therefore, the relatively low numbers of this species collected may explain why NSDV was not isolated in this study. Pools of $R$. appendiculatus, however, did yield single isolates of BHAV and KADV. BHAV has been isolated previously in Kenya and Nigeria $(1,20)$. The medical implications of this virus for humans and animals in this region have not been determined, although the virus has been associated with human infection and illness in eastern Europe and West Africa (21-23). KADV is the only known African tickborne flavivirus. The virus was first isolated from $R$. pravus ticks taken from a cow in Uganda $(24,25)$ and later in Kenya from A. variegatum and $R$. pulchellus (14). Although KADV pathogenicity is not evident in humans, antibodies against KADV were detected in human sera during a serosurvey in Uganda (26).

DUGV is commonly isolated in surveillance studies conducted in Africa $(1,2,27,28)$, and it appears to be endemic in most of the drier parts of the continent. The implications of DUGV for human health have not been evaluated in Kenya, although reports from other regions in Africa suggest that human infection and illness caused by DUGV infection occur $(2,22,27)$. Johnson et al. (1), in an 
earlier study conducted around Lake Victoria, recovered more DUGV isolates than any other virus and observed that more tick pools from dry scrub land (away from the lake) were infected with DUGV than pools from the swamp edge. These researchers also observed that 12 of the 39 DUGV isolates recovered varied in their behavior in cell culture and in suckling mice, which suggests that some of the DUGV strains isolated were different. In our study, in addition to the 26 isolates of DUGV, we identified 2 DUGV-like viruses (6 isolates of one, 1 isolate of another), which were found to differ significantly in S segment nucleotide sequence from previously published DUGV sequences. Further investigation of these isolates is necessary to determine their relatedness to DUGV.

THOV was first isolated in Kenya from Rhipicephalus species and Boophilus decoloratus in the 1930s (29) and has been isolated repeatedly from various tick species in Kenya, West Africa, Europe, and Asia (30). Two THOV infections have been reported in humans, with 1 fatality (22). In our survey, THOV was isolated from pools of $A$. gemma (4), A. lepidum (1), and R. pulchellus (1). DHOV, also a member of the Thogotovirus genus in the Orthomyxovirdae family, has been previously isolated in Europe, Asia, and the Middle East (31-34). Human DHOV infection has been evidenced by serologic survey results and human illness $(23,34,35)$. We report here the first isolation of DHOV in East Africa. This finding suggests a southward spread of the virus that is supported by the presence of competent tick vectors in the region and demonstrates the potential for other tickborne viruses circulating in Europe and Asia to spread to the African continent. Such spread would have adverse consequences for large, immunologically naive populations whose pastoral practices provide for closer human-animal contact.

An unexpected finding in this study was the isolation of FMDV from 3 pools of $R$. pulchellus. FMDV is endemic in many parts of Africa; however, it has not previously been identified in association with tick surveillance or transmission studies (36). This finding does not constitute evidence that FMDV replicates in or can be transmitted by ticks; in fact, previous reports indicate that the virus is not transmissible by Rhipicephalus ticks or blood-feeding flies $(37,38)$. However, the virus has been demonstrated to persist in ticks for up to several days after feeding on an infected animal (37). The ticks in our study were not held for any length of time to allow for blood in the ticks to be digested before processing for virus isolation. Therefore, FMDV may have been present in undigested blood in $\geq 1$ ticks in each pool. FMDV is present in the blood of an infected animal, skin lesions, and skin areas that do not contain lesions (39). The virus persists in skin up to 4 days beyond the period of viremia and for extended periods in preserved hides (40). Therefore, mouth parts of ticks feeding on FMDV-infected cattle might have become contaminated with the virus, which was then not sufficiently exposed to the external rinsing procedures to which the ticks were subjected before processing. Further investigation is necessary to clarify the mechanism of these FMDV isolations and the implications of these findings.

Our study illustrates the potential for tickborne dissemination of endemic and emergent viruses, some of which are human pathogens, among livestock as well as the potential for transmission of these pathogens to humans. Regular surveillance is warranted to monitor the presence and spread of these and other viruses facilitated through livestock rearing, marketing, and movement in Africa.

This work was supported in part by National Institutes of Health grant U54 AI057160 to the Midwest Regional Center of Excellence for Biodefense and Emerging Infectious Diseases Research and in part by the United States Army Medical Research Unit-Kenya. This article is published with permission from the director of Kenya Medical Research Institute.

Dr Sang is a researcher at the Kenya Medical Research Institute's Centre for Virus Research, where she directs the arbovirus/viral hemorrhagic fever laboratory. Her main interest is in the field of arbovirology.

\section{References}

1. Johnson BK, Chanas AC, Squires EJ, Shockley P, Simpson DI, Parsons J, et al. Arbovirus isolations from ixodid ticks infesting livestock, Kano Plain, Kenya. Trans R Soc Trop Med Hyg. 1980;74:732-7.

2. Burt FJ, Spencer DC, Leman PA, Patterson B, Swanepoel R. Investigation of tick-borne viruses as pathogens of humans in South Africa and evidence of Dugbe virus infection in a patient with prolonged thrombocytopenia. Epidemiol Infect. 1996;116:353-61.

3. Guilherme JM, Gonella-Legall C, Legall F, Nakoume E, Vincent J. Seroprevalence of five arboviruses in Zebu cattle in the Central African Republic. Trans R Soc Trop Med Hyg. 1996;90:31-3.

4. Butenko AM, Gromashevsky VL, L'Vov DK, Popov VF. First isolations of Barur virus (Rhabdoviridae) from ticks (Acari: Ixodidae) in Africa. J Med Entomol. 1981;18:232-4.

5. Calisher CH. History, Classification and taxonomy of viruses in the family Bunyaviridae. In: Elliott RM, editor. The Bunyaviridae. New York: Plenum Press; 1996. p. 1-8.

6. Casals J, Tignor GH. The Nairovirus genus: serological relationships. Intervirology. 1980;14:144-7.

7. Clerx JP, Casals J, Bishop DH. Structural characteristics of nairoviruses (genus Nairovirus, Bunyaviridae). J Gen Virol. 1981;55: 165-78.

8. Elliott RM. Emerging viruses: the Bunyaviridae. Mol Med. 1997;3: 572-7.

9. Swanepoel R, Shepherd AJ, Leman PA, Shepherd SP, McGillivray GM, Erasmus MJ, et al. Epidemiologic and clinical features of Crimean-Congo hemorrhagic fever in southern Africa. Am J Trop Med Hyg. 1987;36:120-32. 
10. Burt FJ, Leman PA, Smith JF, Swanepoel R. The use of a reverse transcription-polymerase chain reaction for the detection of viral nucleic acid in the diagnosis of Crimean-Congo haemorrhagic fever. J Virol Methods. 1998;70:129-37.

11. Fisher-Hoch SP, Khan JA, Rehman S, Mirza S, Khurshid M, McCormick JB. Crimean Congo-haemorrhagic fever treated with oral ribavirin. Lancet. 1995;346:472-5.

12. Swanepoel R, Struthers JK, Shepherd AJ, McGillivray GM, Nel MJ, Jupp PG. Crimean-Congo hemorrhagic fever in South Africa. Am J Trop Med Hyg. 1983;32:1407-15.

13. Dunster L, Dunster M, Ofula V, Beti D, Kazooba-Voskamp F, Burt F, et al. First documentation of human Crimean-Congo hemorrhagic fever, Kenya. Emerg Infect Dis. 2002;8:1005-6.

14. Davies FG. Nairobi sheep disease in Kenya. The isolation of virus from sheep and goats, ticks and possible maintenance hosts. J Hyg (Lond). 1978;81:259-65.

15. Matthysse JG, Colbo MH. The ixodid ticks of Uganda together with species pertinent to Uganda because of their present known distribution. College Park (MD): Entomological Society of America; 1987.

16. Okello-Onen J, Hassan SM, Essuman S. Taxonomy of African Ticks Nairobi: ICIPE Science Press; 1999.

17. Beaty BJ, Calisher CH, Shope RE. Arboviruses. In: Lennette EH, Lennette ET, editors. Diagnostic procedures for viral, rickettsial and chlamydial infections. 7th ed. Washington: American Public Heath Association; 1995. p. 204-5.

18. Wang D, Coscoy L, Zylberberg M, Avila PC, Boushey HA, Ganem $\mathrm{D}$, et al. Microarray-based detection and genotyping of viral pathogens. Proc Natl Acad Sci U S A. 2002;99:15687-92.

19. Wang D, Urisman A, Liu YT, Springer M, Ksiazek TG, Erdman DD, et al. Viral discovery and sequence recovery using DNA microarrays. PLoS Biol. 2003;1:257-60.

20. Kemp GE, Causey OR, Moore DL, O’Connor EH. Viral isolates from livestock in northern Nigeria: 1966-1970. Am J Vet Res. 1973;34:707-10.

21. Punda V, Ropac D, Vesenjak-Hirjan J. Incidence of hemagglutination-inhibiting antibodies for Bhanja virus in humans along the northwest border of Yugoslavia. Zentralbl Bakteriol Mikrobiol Hyg [A]. 1987;265:227-34.

22. Moore DL, Causey OR, Carey DE, Reddy S, Cooke AR, Akinkugbe FM, et al. Arthropod-borne viral infections of man in Nigeria, 1964-1970. Ann Trop Med Parasitol. 1975;69:49-64.

23. Filipe AR, Calisher CH, Lazuick J. Antibodies to Congo-Crimean hemorrhagic fever, Dhori, Thogoto and Bhanja viruses in Southern Portugal. Acta Virol. 1985;29:324-8.

24. Henderson BE, Tukei PM, McCrae AW, Ssenkubuge Y, Mugo WN. Virus isolations from Ixodid ticks in Uganda. II. Kadam virus-a new member of arbovirus group B isolated from Rhipicephalus pravus Dontiz. East Afr Med J. 1970;47:273-6.

25. Tukei PM, Williams MC, Mukwaya LG, Henderson BE, Kafuko GW, McCrae AW. Virus isolations from Ixodid ticks in Uganda. I. Isolation and characterisation of ten strains of a virus not previously described from Eastern Africa. East Afr Med J. 1970;47:265-72.
26. Kirya BG, Hewit LE, Lule M, Mujomba A. Arbovirus serology. Report of the East African Virus Research Institute. 1971;20:32-6.

27. Sureau P, Ravisse P, Germain M, Rickenbach A, Cornet JP, Fabre J, et al. Isolement du virus Thogoto a partir de tiques Amblyomma et Boophilus en Afrique centrale. Bull Soc Pathol Exot Filiales. 1976;69:207-12.

28. Wood OL, Lee VH, Ash JS, Casals J. Crimean-Congo hemorrhagic fever, Thogoto, Dugbe, and Jos viruses isolated from ixodid ticks in Ethiopia. Am J Trop Med Hyg. 1978;27:600-4.

29. Karabatsos N, ed. International catalogue of arboviruses. San Antonio (TX): American Society of Tropical Medicine and Hygiene; 1985.

30. Calisher CH, Karabatsos N, Filipe AR. Antigenic uniformity of topotype strains of Thogoto virus from Africa, Europe, and Asia. Am J Trop Med Hyg. 1987;37:670-3.

31. L’Vov DN, Dzharkenov AF, Aristova VA, Kovtunov AI, Gromashevskii VL, Vyshemirskii OI, et al. The isolation of Dhori viruses (Orthomyxoviridae, Thogotovirus) and Crimean-Congo hemorrhagic fever virus (Bunyaviridae, Nairovirus) from the hare (Lepus europaeus) and its ticks Hyalomma marginatum in the middle zone of the Volga delta, Astrakhan region, 2001. Vopr Virusol. 2002;47:32-6.

32. Anderson CR, Casals J. Dhori virus, a new agent isolated from Hyalomma dromedarii in India. Indian J Med Res. 1973;61:1416-20.

33. Filipe AR, Casals J. Isolation of Dhori virus from Hyalomma marginatum ticks in Portugal. Intervirology. 1979;11:124-7.

34. Darwsh MA, Imam ZE, Am T. Antibodies to Dhori and Wanowrie viruses in Egyptian sera. J Egypt Public Health Assoc. 1974;49:362-8.

35. Butenko AM, Leshchinskaia EV, Semashko IV, Donets MA, Mart'ianova LI. Dhori virus - a causative agent of human disease. 5 cases of laboratory infection. Vopr Virusol. 1987;32:724-9.

36. Davies G. Foot-and-mouth disease. Res Vet Sci. 2002;73:195-9.

37. van Vuuren CD. Rhipicephalus zambeziensis unlikely to transmit foot-and-mouth disease virus. Onderstepoort J Vet Res. 1993;60:75-7.

38. Thomson GR. Failure of Haematobia thirouxi potans (Bezzi) to transmit foot-and-mouth disease virus mechanically between viraemic and susceptible cattle. Onderstepoort J Vet Res. 1988;55:121-2.

39. Gailiunas P, Cottral GE. Presence and persistence of foot-and-mouth disease virus in bovine skin. J Bacteriol. 1966;91:2333-8.

40. Gailiunas P, Cottral GE. Survival of foot-and-mouth disease virus in bovine hides. Am J Vet Res. 1967;28:1047-53.

Address for correspondence: Mary Crabtree, Division of Vector-Borne Infectious Diseases, Centers for Disease Control and Prevention, 3150 Rampart Rd, Foothills Campus, Fort Collins, CO 80521, USA; email: mcrabtree@cdc.gov

Use of trade names is for identification only and does not imply endorsement by the Public Health Service or by the U.S. Department of Health and Human Services.

\section{emerging Infectious diseases $\mathrm{O} M \mathrm{line}$}

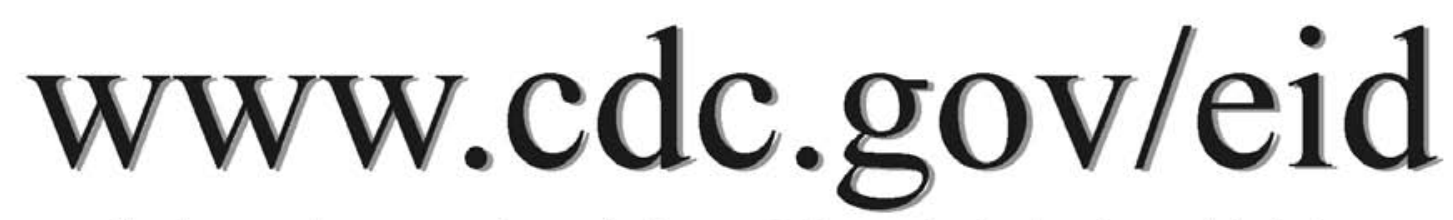

To receive tables of contents of new issues send an email to listserve@cdc.gov with subscribe eid-toc in the body of your message. 